\title{
Sustainable wildlife extraction and the impacts of socio-economic change among the Kukama- Kukamilla people of the Pacaya-Samiria National Reserve, Peru
}

\author{
Maire Kirkland, Cristina Eisenberg, Andy Bicerra, Richard E. Bodmer \\ PEDRO MAYOR and JAN C. AXMACHER
}

\begin{abstract}
Throughout the tropics, hunting and fishing are critical livelihood activities for many Indigenous peoples. However, these practices may not be sustainable following recent socio-economic changes in Indigenous populations. To understand how human population growth and increased market integration affect hunting and fishing patterns, we conducted semi-structured interviews in five Kukama-Kukamilla communities living along the boundary of the Pacaya-Samiria National Reserve, in the Peruvian Amazon. Extrapolated annual harvest rates of fish and game species by these communities amounted to $1,740 \mathrm{t}$ and 4,275 individuals (67 t), respectively. At least 23 fish and 27 game species were harvested. We found a positive correlation between village size and annual communitylevel harvest rates of fish and a negative relationship between market exposure and mean per-capita harvest rates of fish. Catch-per-unit-effort (CPUE) analyses indicated local depletion of fish populations around larger, more commercial communities. Catch-per-unit-effort of fish was lower in more commercial communities and fishers from the largest village travelled further into the Reserve, where CPUE was higher. We found no effect of village size or market exposure on harvest rates or CPUE of game species. However, larger, more commercial communities targeted larger, economically valuable species. This study provides evidence that human population growth and market-driven hunting and fishing pose a growing threat to wildlife and Indigenous livelihoods through increased harvest rates and selective harvesting of species vulnerable to exploitation.
\end{abstract}

MAIRE KirKLAND ${ }^{*} \dagger$ (Corresponding author), ANdy Bicerra, Richard E. Bodmer $\ddagger$ and Pedro Mayor§ Fund Amazonia, Calle Malecón Tarapacá No 332, Iquitos, Peru. E-mail maire.kirkland@durham.ac.uk

CRISTINA EISENBERg Earthwatch, Boston, Massachussets, USA

Jan C. Axmacher Department of Geography, University College London, London, UK

*Also at: Durham University, Durham, UK

$\dagger$ Also at: Department of Geography, University College London, London, UK $\ddagger$ Also at: University of Kent, Canterbury, UK

$§$ Also at: Universitat Autònoma de Barcelona, Barcelona, Spain

Received 9 September 2017. Revision requested 12 December 2017.

Accepted 15 December 2017. First published online 4 September 2018.
Keywords Amazon, catch-per-unit-effort, fishing, hunting, Indigenous peoples, Peru, protected area, sustainability

\section{Introduction}

T $\mathrm{n}$ tropical forests hunting and fishing are crucial to the livelihoods of Indigenous peoples as a source of protein and income (East et al., 2005). A growing number of studies suggest current harvests of a variety of species exceed sustainable levels, causing widespread population declines and local extinctions (Abernethy et al., 2013; Castello et al., 2014; Morcatty \& Valsecchi, 2015; Parry \& Peres, 2015). As a result there is a debate between those who view the presence of Indigenous peoples in protected areas as a direct threat to biodiversity and those who view such Indigenous peoples as conservation allies (da Silva et al., 2005; Ohl-Schacherer et al., 2007). In-depth monitoring of hunting and fishing is a key prerequisite for promoting the sustainable use of natural resources, avoiding extinctions of important species while preserving the rights of Indigenous peoples to land, traditions and culture.

The decreasing sustainability of hunting and fishing practices has been attributed in part to the rapid growth in Indigenous populations and their integration into the market economy. These trends have triggered powerful socio-economic changes, leading to an increasing demand for wildlife products from both the rural and urban populations and a growing economic incentive to hunt and fish commercially (McSweeney \& Jokisch, 2007; Ohl-Schacherer et al., 2007; Suarez et al., 2009; Fa et al., 2015). Simultaneously, improved technologies and transportation have enhanced the capacity of an increasing number of hunters and fishers to capture prey, including in previously inaccessible areas (Wilkie et al., 2000; Godoy et al., 2010; Foerster et al., 2012). Yet, empirical studies have revealed mixed and even positive effects of socio-economic development on wildlife harvesting (Lu, 2007). For example, opportunities for permanent and well-paid jobs combined with a preference among wealthier households for alternative protein sources such as storepurchased meat can lead to a reduction in wildlife harvesting (Wilkie \& Godoy, 2001; Gray et al., 2015; Vasco \& Sirén, 2016). Understanding the complex interactions between 
socio-economic factors and extractive activities in a variety of social, cultural and natural contexts remains imperative, especially given the need to alleviate poverty among Indigenous peoples.

In the Peruvian Amazon hunting and fishing constitute integral components of the Kukama-Kukamilla culture. This Indigenous group harvests a large variety of natural resources from surrounding areas, which include the Pacaya-Samiria National Reserve. In the past, a strict protectionist system in this Reserve provoked a backlash of rampant poaching and overexploitation by the local people (Bodmer et al., 2008). In the late 1990s a new Reserve administration adopted a co-management approach, permitting low levels of hunting and fishing by the local people. Since then, populations of key species have been increasing in the Reserve, including threatened species such as the Vulnerable woolly monkey Lagothrix poeppigii, the Vulnerable lowland tapir Tapirus terrestris and the paiche Arapaima gigas (Bodmer \& Puertas, 2007). However, like many other Amazonian communities, the KukamaKukamilla are undergoing rapid socio-economic changes that could once again increase pressure on wildlife.

We aimed to explore how socio-economic factors influence the hunting and fishing patterns of the Kukama-Kukamilla people. Our findings provide insights into the factors that underpin sustainable resource use, specifically the threats of human population growth and market-driven hunting and fishing brought about by rural development. Previous studies have generally explored the effects of socio-economic conditions on wildlife harvesting between households. However, because households within a community harvest wildlife from a communal catchment area, we explored the combined impacts of wildlife harvesting by the community as a whole. Through the use of semistructured interviews, we tested the hypothesis that larger communities with greater access to the economic market exert higher pressure on wildlife and target more commercially valuable species. These communities are expected to be affected by higher levels of wildlife depletion, with preferred species disappearing near villages, triggering shifts in the spectrum of species harvested.

\section{Study area}

This study was carried out in the 2,080,000 ha Pacaya-Samiria National Reserve in the Department of Loreto, in the north-eastern Peruvian Amazon. It is bordered by two tributaries of the Amazon River, the Ucayali and Marañón rivers, and encompasses the two major drainage basins of the Pacaya and Samiria rivers. The Reserve is characterized by massive hydrological fluctuations that occur between the high-water (October-May) and lowwater (June-September) seasons (Kvist et al., 2001).
The majority of inhabitants are descendants of the Tupi-Guarani speaking Kukama-Kukamilla people and more recent immigrants of Caucasian and Indigenous origin (Gow, 2007). Their main livelihood activity is fishing, which is most productive during the low-water season, when fish become trapped in shrinking water bodies. Nonetheless, migrations of fish feeding on fallen fruit in the várzeas (white-water flooded forests) make some fisheries productive during the high-water season (Kvist et al., 2001). The Kukama-Kukamilla also engage in opportunistic hunting, primarily during the high-water season, when the terrestrial fauna is concentrated on the non-inundated restingas (levees; Bodmer et al., 1998).

Approximately 100,000 people live in over 200 communities along the boundary of the Pacaya-Samiria National Reserve (INRENA, 2009). We selected five KukamaKukamilla villages located at the mouth of the Samiria River, which were divided into two distinct areas: (1) San Martín de Tipishca, Nuevo Arica and Bolivar lie on the shores of Tipishca Lake; and (2) San José de Samiria and Leoncio Prado are located along the Marañón River (Fig. 1). These villages contain 40-120 households (Table 1), and differ in their exposure to the market economy. The communities of the Marañon River supply produce to the urban markets of Loreto by selling to freezer vessels or directly to market vendors.

\section{Methods}

\section{Data collection}

We conducted 122 semi-structured interviews, which accounted for $34.9 \%$ of households within the study area, during June-August 2013 (Table 1). The use of semi-structured interviews was the preferred data collection method, as they allow emphasis on specific topics depending on the interviewees' knowledge and experience (Rubin \& Rubin, 2005). Recall bias was expected to be minimal, as quantitative information requested was simple and activities are regular and highly seasonal (Golden et al., 2013). All households were found to be dependent on hunting and/or fishing, so we adopted a convenience sampling approach, selecting the most accessible households (Patton, 2002). We targeted male heads of households for interviews, but in some cases interviewed women instead, either because they too participated in hunting or fishing, or more often because they had acquired detailed information about harvests through cooking. We obtained informed consent from participants before conducting interviews.

The social sensitivity of the topic being explored may have created some bias in the data, resulting in the under-representation of harvests. Where possible, we used participant observation to verify interview responses. We informed interviewees that no information gathered would 

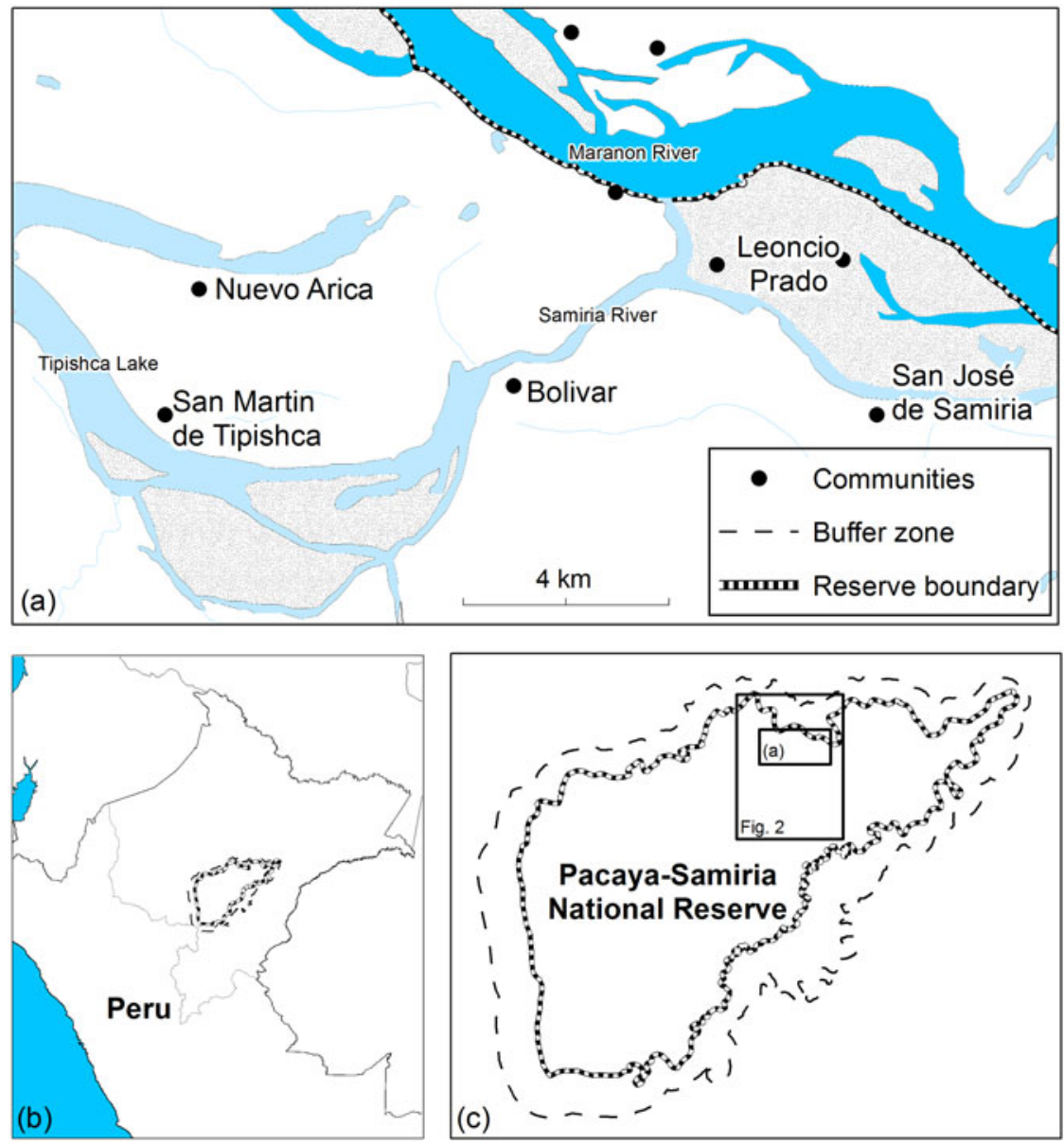

FIg. 1 The study area at the mouth of the Samiria River, showing (a) the five Kukama-Kukamilla settlements, (b) the location of the Reserve in Peru, and (c) the location of the study area in the Pacaya-Samiria National Reserve. be used against them and that survey information would be anonymized.

\section{Data analysis}

We obtained household harvest rates of fishing by asking fishers to state the mean total biomass of fish caught per day, during high- and low-water seasons separately. This was extrapolated to annual harvest rates by multiplying each estimate of mean daily yield for each season by 182.5 (6 months). A limitation of using interviews to collect harvest data was that fishers were unable to state the quantity of each species harvested, because they measure the weight of the entire catch. We therefore recorded the per cent of households that harvest each species, using these data as proxies for relative harvest rates. We obtained annual household harvest rates of game species by asking hunters to state the mean number of wild animals hunted per year for each species, as hunting is less frequent than fishing. This was converted to biomass using body weight data (Peres \& Dolman, 2000; Ohl-Schacherer et al., 2007; Cardoso et al., 2012; Mayor et al., 2015). We calculated per-capita harvest rates, assuming an average of six individuals per household. We determined total community-level harvest rates of fish by multiplying mean household harvest rates by the number of households in each community, and in the case of game species, by the per cent of households that engage in hunting.

We used household harvest rates to estimate catch-perunit-effort (CPUE). The assumption of CPUE as an indicator of sustainability is that hunters and fishers must increase their efforts in areas with depleted populations to achieve the required meat and fish return rates. A difference in CPUE is assumed to reflect a difference in prey density or abundance (Rist et al., 2010). We calculated CPUE of fish as $Y / H$ and CPUE of game species as $B / D$, where $Y$ is the total daily yield of fish harvested, $H$ is the number of hours per day fishers leave their nets in the water (the most common method), $B$ is the total biomass of games species hunted annually, and $D$ is the number of days per year hunters are active. We averaged across households to obtain community-level CPUE estimates.

We calculated the distance travelled on hunting and fishing trips using reports of average time travelled. Based on information given by a local informant, we estimated that $6 \mathrm{~km}$ were travelled in 1 hour in peque peque (motorized canoe) and $4 \mathrm{~km}$ on foot. As hunters use watercourses to navigate to hunting sites and limit their activities to within $2 \mathrm{~km}$ into the forest from the river's edge, distance travelled 


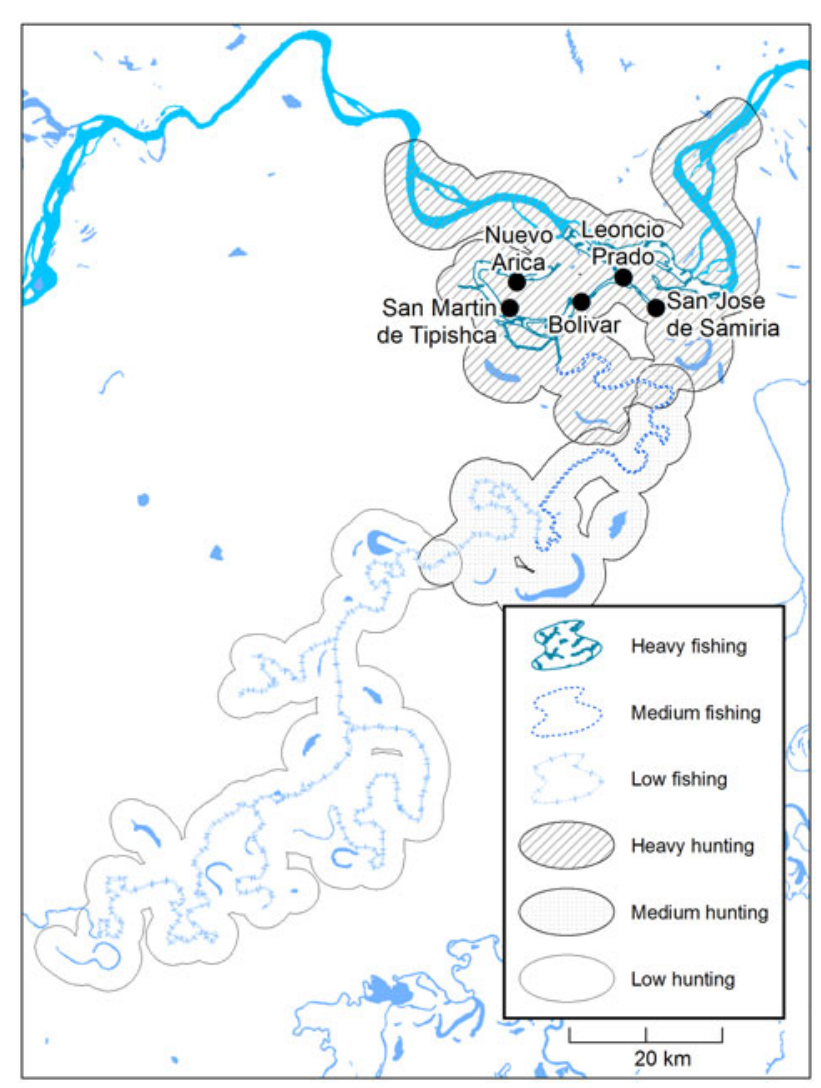

FIG. 2 The hunting and fishing catchment area of the Kukama-Kukamilla communities at the mouth of the Samiria River (Fig. 1), showing zones of heavy, medium and low exploitation based on travelling patterns provided by interviewees.

was multiplied by four to obtain the size of the total catchment area (Begazo \& Bodmer, 1998). The corresponding catchment area was drawn around the channels and lakes of the Samiria and Marañón rivers and divided into zones of low, medium and heavy exploitation, using the maximum distances travelled by the top 25 and 50 percentiles as the thresholds (Fig. 2). Given our project's social science dimension and use of interviews, we determined that this measure of relative exploitation was appropriate (Brodizio \& Chowdhury, 2010; Hawken \& Munch, 2012). We used Welch's analysis of variance and the Kruskal-Wallis $H$ test to compare distance travelled on hunting and fishing trips between communities. Pearson's rank correlation coefficient allowed us to examine the relationship between CPUE and distance travelled as an indication of local resource depletion (Fa et al., 2006; Laurance et al., 2006).

We used multiple linear regressions to investigate the effects of socio-economic variables on CPUE and harvest rates. We included village size as a continuous variable and market exposure as a categorical variable in all models, using season as an additional categorical variable in the analyses of fishing data. The response variables were logtransformed to account for non-normal distributions. We estimated the significance of variables by dropping them from the full model and using likelihood ratio tests to compare nested models. We examined variations in the species compositions of harvests, termed the harvest profile, using Principal Components Analysis (PCA). Results were considered significant at $\mathrm{P}<0.05$. Statistical analyses were undertaken in $R$ 3.3.1 (R Development Core Team, 2016).

\section{Results}

All households in the study area fished daily throughout the year. In $57 \%$ of households, fishing was supplemented with hunting. Seventy-seven per cent of hunters were active for $<$ 10 days per year, and only one hunted as often as 18 days per year. The total biomass of wildlife harvested annually by the five communities was c. 1,807 t (Table 1 ). The majority of fishers (96\%) reported travelling in peque peque for no more than 6 hours, whereas $39 \%$ of hunters undertook trips of several days, travelling over 6 hours to reach remote restingas inside the Reserve. The mean distance travelled by fishers and hunters was $11.2 \pm$ SE $4.1 \mathrm{~km}$ and $44.0 \pm$ SE $11.1 \mathrm{~km}$, respectively. The distance travelled on hunting trips did not differ between communities $\left(H_{(4)}=5.70, \mathrm{P}=0.22\right)$, but fishers from Nuevo Arica and San Martín de Tipishca travelled further than fishers from other villages (Welch's $F_{(4,29.67)}=18.21, \mathrm{P}<0.001$ ). The combined hunting and fishing catchment area for all communities covered c. $576 \mathrm{~km}^{2}$ (Fig. 2). There was a positive correlation between distance travelled into the Reserve and CPUE for fish during the low-water season (Pearson $\left.r_{\mathrm{s}(120)}=0.22, \mathrm{P}=0.017\right)$, but not the high-water season (Pearson $\left.r_{\mathrm{s}(120)}=0.17, \mathrm{P}=0.07\right)$. There was no significant correlation between distance travelled and CPUE of game species (Pearson $r_{\mathrm{s}(69)}=0.14, \mathrm{P}=0.24$ ).

The communities of the Samiria basin collectively harvested c. 1,740 t of fish annually ( $96.3 \%$ of biomass extracted), comprising 23 fish species (Table 2). The most widely caught species was Prochilodus nigricans, a species of both commercial and subsistence importance. There was substantial variation in harvest profiles between communities (Fig. 3a). In San José de Samiria and Leoncio Prado fishers harvested a large proportion of small, commercial species such as Leporinus spp., as well as larger species such as Hoplias malabaricus. In San José de Samiria, smaller, less economically valuable species such as Oxydoras niger and Leiarius marmoratus also made up a significant proportion of the catch. The communities of Tipishca Lake depended on the most abundant species, including Pterygoplichthys pardalis, Pygocentrus spp. and Serrasalmus spp. We found evidence that the paiche, a species of conservation concern (INRENA, 2009), was also caught.

The reported total annual harvest of game species in the study area was c. 4,275 individuals, equating to c. $67 \mathrm{t}(3.7 \%$ of biomass extracted) and comprising 27 species (Table 3 ). 
TABLE 1 Details of interviews and harvest rates in the five Kukama-Kukamilla communities located at the mouth of the Samiria River (Figs. 1 \& 2). The amount of meat available for consumption refers to the edible portion of fish and game meat, which was calculated as $70 \%$ of biomass extracted (Hill et al., 1984; Roos et al., 2007).

\begin{tabular}{|c|c|c|c|c|c|}
\hline & San Martín de Tipishca & Nuevo Arica & Bolivar & Leoncio Prado & San José de Samiria \\
\hline Number of families & 120 & 50 & 40 & 90 & 50 \\
\hline Number interviewed (\%) & $29(24.2 \%)$ & $28(56.0 \%)$ & $9(22.5 \%)$ & $30(33.3 \%)$ & $26(52.0 \%)$ \\
\hline \multicolumn{6}{|c|}{ Total community-level harvest per year $(t)$} \\
\hline Fish & 679.64 & 222.26 & 359.32 & 327.95 & 151.26 \\
\hline Game & 15.01 & 14.42 & 8.40 & 9.94 & 10.70 \\
\hline Total meat & 694.65 & 236.68 & 367.72 & 337.89 & 161.96 \\
\hline \multicolumn{6}{|c|}{ Total harvest per capita per year $(t)$} \\
\hline Fish & 0.94 & 0.74 & 1.50 & 0.61 & 0.51 \\
\hline Game & 0.04 & 0.09 & 0.06 & 0.03 & 0.06 \\
\hline Total meat & 0.98 & 0.83 & 1.56 & 0.64 & 0.57 \\
\hline \multicolumn{6}{|c|}{ Total meat available for consumption } \\
\hline Per household per year (t) & 4.11 & 3.47 & 6.55 & 2.68 & 2.39 \\
\hline Per capita per year $(\mathrm{t})$ & 0.68 & 0.58 & 1.09 & 0.45 & 0.40 \\
\hline Per capita per day $(\mathrm{kg})$ & 1.88 & 1.59 & 2.99 & 1.22 & 1.09 \\
\hline
\end{tabular}

TABLE 2 Fish species harvested by the Kukama-Kukamilla people, showing the proportion of households harvesting each species during high- and low-water seasons. None of these species have yet been assessed for the IUCN Red List (2017).

\begin{tabular}{|c|c|c|c|}
\hline \multirow[b]{2}{*}{ Species (by Order) } & \multirow[b]{2}{*}{ Local name } & \multicolumn{2}{|c|}{$\begin{array}{l}\text { Percentage of } \\
\text { households } \\
(\%)\end{array}$} \\
\hline & & High & Low \\
\hline \multicolumn{4}{|l|}{ Characiformes } \\
\hline Prochilodus nigricans & Boquichico & 83.33 & 77.12 \\
\hline Hoplerythrinus unitaeniatus & Shuyo & 60.83 & 41.18 \\
\hline Mylossoma duriventre & Palometa & 26.67 & 45.00 \\
\hline Hoplias malabaricus & Fasaco & 26.67 & 28.57 \\
\hline Triportheus spp. & Sardina & 25.00 & 22.69 \\
\hline Leporinus spp. & Lisa & 15.83 & 22.69 \\
\hline Pygocentrus/Serrasalmus spp. & Piraña & 14.17 & 17.65 \\
\hline Potamorhina latior & Yahuarachi & 6.67 & 4.20 \\
\hline Brycon spp. & Sabalo & 5.83 & 5.74 \\
\hline Colossoma macropomum & Gamitana & 0.83 & 0.83 \\
\hline \multicolumn{4}{|l|}{ Perciformes } \\
\hline Satanoperca jurupari & Bujurqui vaso & 15.00 & 23.33 \\
\hline Astronotus ocellatus & Acarahuazú & 9.17 & 26.27 \\
\hline Cichla monoculus & Tucunaré & 0.83 & 6.67 \\
\hline \multicolumn{4}{|l|}{ Siluriformes } \\
\hline Pterygoplichthys pardalis & Carachama & 64.17 & 51.28 \\
\hline Pseudoplatystoma tigrinum & Tigre zúngaro & 4.17 & 5.83 \\
\hline Pimelodus blochii & Bagre & 3.33 & 4.17 \\
\hline Pseudoplatystoma fasciatum & Doncella & 3.33 & 2.50 \\
\hline Hoplosternum spp. & Shirui & 2.50 & 0.83 \\
\hline Hypophthalmus edentatus & Maparate & 0.83 & 1.67 \\
\hline Oxydoras niger & Turushuqui & 0.83 & 0.83 \\
\hline Leiarius marmoratus & Achara & 0.83 & 0.83 \\
\hline Sorubim lima & Shiripira & 0.83 & 0.00 \\
\hline
\end{tabular}

Mammals were the most frequently extracted group, comprising $74.0 \%$ of hunted biomass and $56.0 \%$ of all hunted individuals, followed by reptiles $(23.1,19.1 \%)$ and birds (2.9,
$24.9 \%)$. The majority of biomass harvested came from largebodied animals, mainly the white-lipped peccary Tayassu pecari, lowland tapir, and black caiman Melanosuchus niger. The white-lipped peccary, paca Cuniculus paca and brown agouti Dasyprocta variegata were the most frequently hunted in terms of number of individuals. The Amazonian manatee Trichechus inunguis, which is strictly protected, was hunted occasionally. As with fish harvests, harvest profiles of game species varied substantially between communities (Fig. 3b). In San José de Samiria and San Martín de Tipishca, hunters harvested a larger proportion of largebodied species, such as the lowland tapir, the South American river turtle Podocnemis expansa and the whitelipped peccary, whereas the other communities harvested a larger proportion of small primates and wetland birds.

The multiple linear regressions revealed a significant positive relationship between annual community-level harvest rates of fish and village size (Table 4, Fig. 4). However, village size had no effect on mean per-capita harvest rates $(F=0.33$, $\mathrm{P}=0.59)$ or CPUE $(F=0.96, \mathrm{P}=0.37)$ of fish. There was no effect of market exposure on community-level harvest rates of fish $(F=4.60, \mathrm{P}=0.08)$, but commercial communities had significantly lower mean per-capita harvest rates and CPUE of fish (Table 4, Fig. 5). As expected, season had a significant effect on harvest rates and CPUE of fish, both of which were higher in the low-water season (Table 4). Neither market exposure nor village size had a significant effect on harvest rates or CPUE of game species (all $\mathrm{P}>0.31$ ).

\section{Discussion}

Our study adds to the growing body of research that suggests socio-economic factors influence wildlife harvesting by Indigenous peoples (Smith \& Wishnie, 2000; Lu, 2007; Godoy et al., 2010). Specifically, the patterns of hunting 

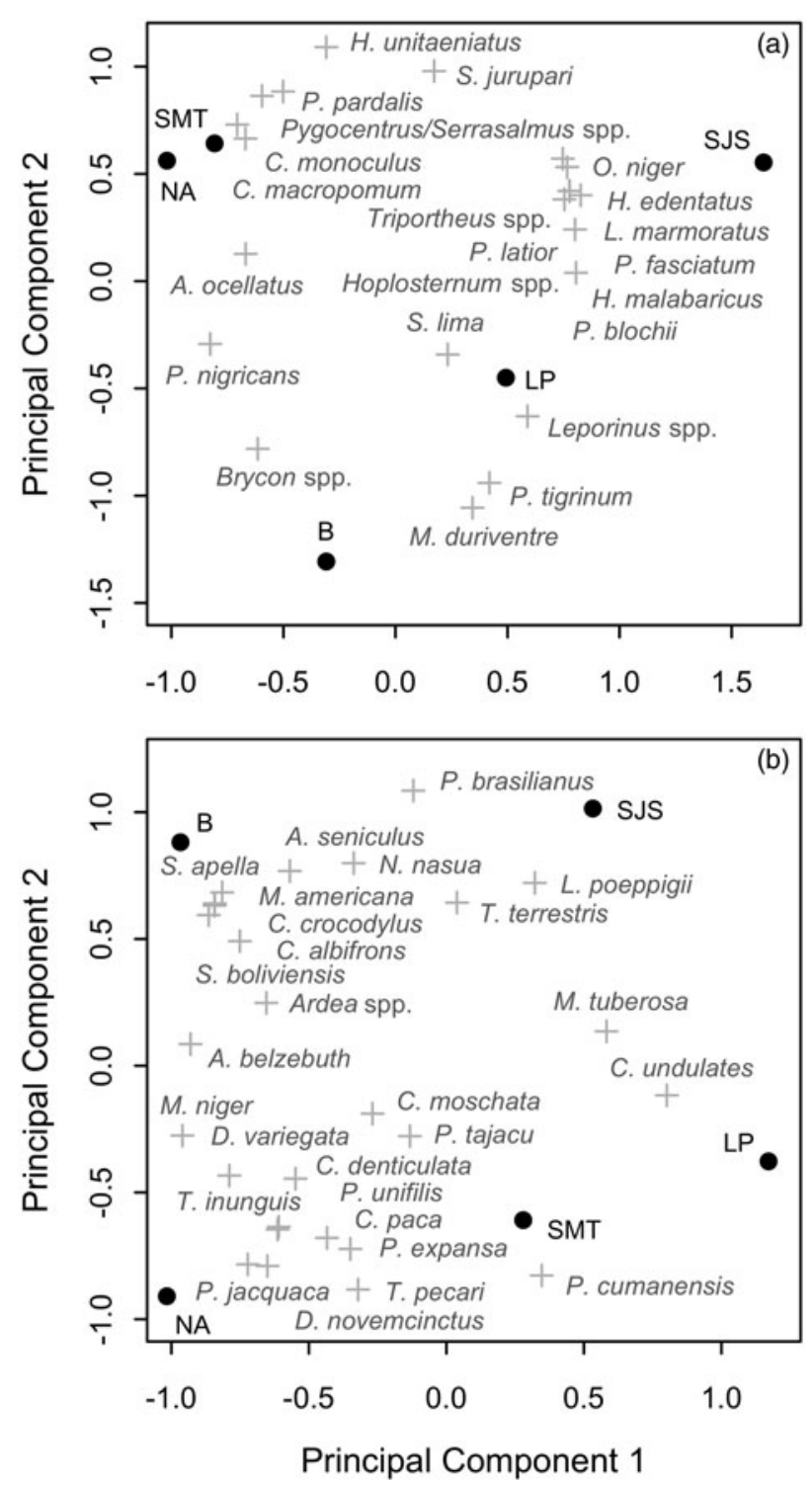

FIG. 3 Ordination axes based on species composition of (a) fish harvests and (b) game harvests, showing communities $(\bullet)$ and species (+). SMT, San Martín de Tipishca; NA, Nuevo Arica; B, Bolivar; LP, Leoncio Prado; SJS, San José de Samiria.

and fishing by the Kukama-Kukamilla people of the Pacaya-Samiria National Reserve reveal the potential threat of increased market integration and an increasing human population. The data presented in this study include a number of potential sources of variation that we did not control for, including environmental variables such as habitat quality, which may have limited the statistical power of the analyses. Furthermore, the small sample size of only five communities means the results of the significance tests should be interpreted cautiously. However, because data points are aggregates of household-level data, they reflect many more underlying observations, and we believe this allows us to make reliable inferences.
We uncovered evidence that increased market exposure leads to resource depletion, reflected in a lower CPUE of fish in commercial communities. A reduction in fish populations as a result of overfishing may have reduced the profitability of fishing and limited commercial fishing activity, which would explain why fishers in commercial communities had lower mean per-capita harvest rates (Vasco \& Sirén, 2016). Nevertheless, the net pressure that commercial fishing puts on depleted resources is probably greater than the pressure exerted by non-commercial communities on relatively undepleted fish stocks. In San José de Samiria and Leoncio Prado, fishers targeted small, economically valuable species, indicating possible overexploitation of larger species. This trend is observed in the nearby markets of Iquitos, where the sale of cheaper, smaller and faster-growing species has risen since the 1980 s and the sale of larger species has declined (Garcia et al., 2008; Atwood et al., 2015). The large proportion of less economically valuable species in harvests from San José de Samiria could reflect an increasing reliance on these species for subsistence.

As expected, larger communities exerted greater pressure on fish resources through increased harvest rates, because there are both more people to feed and a greater number of fishers. We therefore expected to see similar signs of resource depletion in these communities. Nonetheless, community size had no significant effect on CPUE of fish. However, fishers from San Martín de Tipishca, the largest village, together with those from Nuevo Arica, travelled further on fishing trips than those from neighbouring communities, and during the low-water season CPUE was higher further into the Reserve. This is consistent with the paradigm that Neotropical people are central-place foragers, travelling greater distances in search of preferred prey species as wildlife populations become locally depleted (Levi et al., 2009, 2011). Thus, fishing in previously unexploited sites inside the Pacaya-Samiria National Reserve could be masking resource depletion in Tipishca Lake. Fishers from San Martín de Tipishca also harvested small, abundant fish species, which may be able to sustain the larger human population.

We found no clear effect of village size or market exposure on harvest rates or CPUE of game species. This implies that people in larger, commercial villages have been able to shift to alternative sources of protein, such as fish or livestock, to meet subsistence and commercial needs. The strong presence of preferred species in harvest profiles suggests that wild meat harvests in the Pacaya-Samiria National Reserve are currently supplied by a relatively undepleted source. In San José de Samiria and San Martín de Tipishca, hunters harvested large-bodied prey species, including ungulates, large primates and reptiles. Encounter rates of these species in the forest are relatively low as a result of naturally low population densities, so hunters are 
TABLE 3 Annual per-capita harvest rates (biomass and number of individuals) of game species by the Kukama-Kukamilla people, with the IUCN Red List status (IUCN, 2017).

\begin{tabular}{|c|c|c|c|c|c|}
\hline \multirow[b]{2}{*}{ Order (by Class) } & \multirow[b]{2}{*}{ Species } & \multirow[b]{2}{*}{ Local name } & \multirow[b]{2}{*}{ Red List status ${ }^{*}$} & \multicolumn{2}{|c|}{ Annual per-capita harvest } \\
\hline & & & & Biomass (kg) & No. of individuals \\
\hline \multicolumn{6}{|l|}{ Mammalia } \\
\hline \multirow[t]{3}{*}{ Artiodactyla } & Tayassu pecari & Huangana & VU & 17.33 & 0.50 \\
\hline & Pecari tajacu & Sajino & $\mathrm{LC}$ & 2.60 & 0.10 \\
\hline & Mazama americana & Venado colorado & $\mathrm{DD}$ & 1.02 & 0.05 \\
\hline Perissodactyla & Tapirus terrestris & Sachavaca & VU & 13.19 & 0.10 \\
\hline \multirow[t]{2}{*}{ Rodentia } & Cuniculus paca & Majáz & $\mathrm{LC}$ & 3.38 & 0.42 \\
\hline & Dasyprocta variegata & Añuje & $\mathrm{DD}$ & 1.63 & 0.33 \\
\hline Sirenia & Trichechus inunguis & Vaca marina & VU & 2.90 & 0.01 \\
\hline Cingulata & Dasypus novemcinctus & Carachupa & $\mathrm{LC}$ & 1.61 & 0.27 \\
\hline \multirow[t]{6}{*}{ Primates } & Alouatta seniculus & Coto & $\mathrm{LC}$ & 1.19 & 0.18 \\
\hline & Sapajus apella & Mono negro & LC & 0.25 & 0.09 \\
\hline & Cebus albifrons & Mono blanco & $\mathrm{LC}$ & 0.19 & 0.07 \\
\hline & Saimiri boliviensis & Fraile & $\mathrm{LC}$ & 0.18 & 0.02 \\
\hline & Lagothrix poeppigii & Choro & VU & 0.04 & 0.01 \\
\hline & Ateles belzebuth & Maquisapa & EN & 0.01 & 0.02 \\
\hline Carnivora & Nasua nasua & Achuni & $\mathrm{LC}$ & 0.17 & 0.03 \\
\hline \multicolumn{6}{|l|}{ Reptilia } \\
\hline \multirow[t]{2}{*}{ Crocodilia } & Melanosuchus niger & Lagarto negro & $\mathrm{LC}$ & 7.00 & 0.15 \\
\hline & Caiman crocodilus & Lagarto blanco & $\mathrm{LC}$ & 1.60 & 0.05 \\
\hline \multirow[t]{3}{*}{ Testudinae } & Podocnemis unifilis & Taricaya & VU & 2.78 & 0.35 \\
\hline & Chelonoidis denticulata & Motelo & VU & 1.02 & 0.13 \\
\hline & Podocnemis expansa & Charapa & $\mathrm{LC}$ & 1.88 & 0.07 \\
\hline \multicolumn{6}{|l|}{ Aves } \\
\hline Anseriformes & Cairina moschata & Sachapato & $\mathrm{LC}$ & 0.58 & 0.19 \\
\hline \multirow[t]{3}{*}{ Galliformes } & Mitu tuberosum & Paujil & $\mathrm{LC}$ & 0.29 & 0.10 \\
\hline & Pipile cumanensis & Pava & $\mathrm{LC}$ & 0.22 & 0.16 \\
\hline & Penelope jacquacu & Pucacunga & LC & 0.15 & 0.12 \\
\hline \multirow[t]{2}{*}{ Pelecaniformes } & Phalacrocorax brasilianus & Cushuri & $\mathrm{LC}$ & 0.25 & 0.17 \\
\hline & Ardea spp. & Garza & & 0.24 & 0.20 \\
\hline Tinamiformes & Crypturellus undulatus & Panguana & $\mathrm{LC}$ & 0.04 & 0.04 \\
\hline
\end{tabular}

${ }^{\star}$ LC, Least Concern; DD, Data Deficient; VU, Vulnerable; EN, Endangered.

probably targeting them for their greater meat harvests, as occurs in other Amazonian communities (Peres \& Lake, 2003; Zapata-Ríos et al., 2009; Espinosa et al., 2014; Sirén \& Wilkie, 2016). The current hunting patterns of the Kukama-Kukamilla people may be indicative of a sourcesink dynamic, with immigration of game species from the unhunted core zone of the Reserve sustaining harvests in the catchment area (Navaro et al., 2000; Ohl-Schacherer et al., 2007).

Nevertheless, large-bodied game species are particularly vulnerable to overexploitation because of slow reproductive rates (Mayor et al., 2017). The continued harvest of vulnerable species by larger, commercial communities will probably cause significant population declines in the Pacaya-Samiria National Reserve and a shift in prey selection towards a broader range of smaller, less-preferred species, following the general trend throughout the Amazon (Naranjo \& Bodmer, 2007; Peres \& Palacios, 2007; Constantino, 2016). The region has also been experiencing more extreme droughts and seasonal flooding since 2009, which could exacerbate the impacts of unsustainable wildlife extraction by limiting resources for wildlife and causing direct mortality of animals (Bodmer et al., 2017). The recent sharp decline in populations of the white-lipped peccary throughout its range, for which non-anthropogenic impacts are suspected, will put further pressure on alternative and more vulnerable prey species (Fragoso, 2004; Richard-Hansen et al., 2013; Mayor et al., 2015).

Overall, our results indicate that the forests of the Pacaya-Samiria National Reserve are able to provide important food supplements for the Kukama-Kukamilla people. However, hunting and fishing in some villages appears to be approaching critical thresholds, threatening the natural capital of the Reserve. Globally, the combination of human population growth and increased market integration of Indigenous peoples is linked to a downward spiral of local species extinctions and a diminishing supply of crucial protein and income. In this context, the sustainable 
TABLE 4 Results of the multiple linear regression analyses showing the effect of village size, market exposure and season on logtransformed harvest rates and CPUE. Non-significant variables were excluded from each model.

\begin{tabular}{lrrr}
\hline \multicolumn{1}{c}{ Estimate $\pm \mathrm{SE}$} & \multicolumn{1}{c}{$t$} & \multicolumn{1}{c}{$\mathrm{P}$} \\
\hline Community-level harvest rates & & \\
Intercept & $3.41 \pm 0.35$ & 9.74 & $<0.000$ \\
Village size & $0.01 \pm 0.00$ & 2.66 & 0.032 \\
Low-water season & $1.25 \pm 0.26$ & 4.80 & 0.002 \\
Per-capita harvest rates & & & \\
Intercept & $-1.52 \pm 0.18$ & -8.61 & $<0.000$ \\
Commercial & $-0.54 \pm 0.22$ & -2.44 & 0.045 \\
Low-water season & $1.25 \pm 0.22$ & 5.76 & $<0.001$ \\
CPUE & & & \\
Intercept & $-0.80 \pm 0.14$ & 5.73 & $<0.001$ \\
Commercial & $-1.10 \pm 0.17$ & -6.27 & $<0.001$ \\
Low-water season & $1.61 \pm 0.17$ & 6.78 & $<0.001$ \\
\hline
\end{tabular}

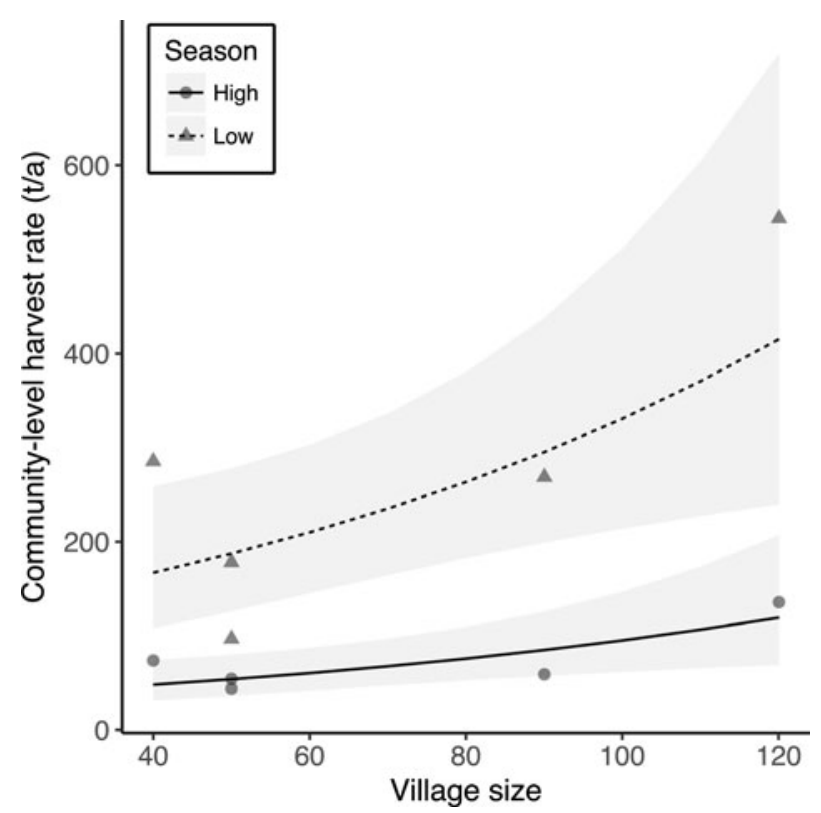

FIG. 4 The effect of village size (number of households) on annual community harvest rates of fish during the high- and low-water seasons in the five Kukama-Kukamilla communities at the mouth of the Samiria River (Figs 1 \& 2). The grey symbols represent the raw data, the lines are the predicted slopes from the linear regression model, and the shaded areas are the $95 \%$ confidence intervals.

management of natural resources represents a crucial opportunity for biodiversity conservation where protected areas and Indigenous territories overlap (Zimmerman et al., 2001). Development professionals, protected area managers and conservationists need to help maintain low hunting and fishing pressure by diversifying and enhancing existing livelihood strategies, thereby reducing poverty in rural communities and conserving vulnerable species (Bodmer \& Lozano, 2001; Bassett, 2005; Gandiwa, 2011). Community-based management is needed to monitor the
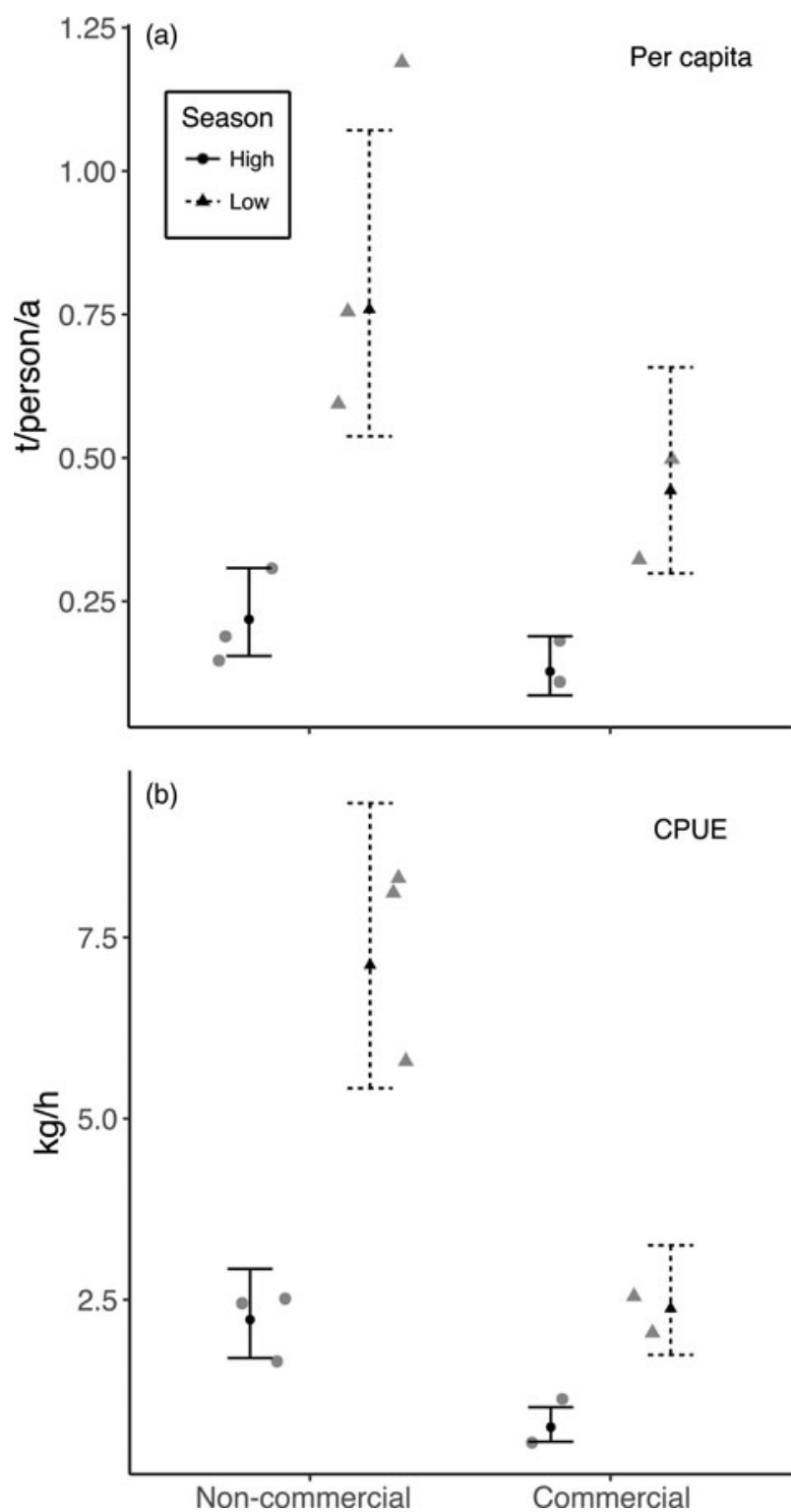

FIG. 5 The effect of market exposure on (a) annual mean per-capita harvest rates and (b) mean daily CPUE of fish (as kg per $\mathrm{h}$ of nets in the water) in the five Kukama-Kukamilla communities located at the mouth of the Samiria River (Figs 1 \& 2), with the raw data (grey symbols), the predicted means (black symbols) from the linear regression model and 95\% confidence intervals.

impacts of socio-economic and climatic change, and to ensure the long-term sustainable use of forest species, both inside and outside protected areas.

Acknowledgements We are indebted to the communities of the Pacaya-Samiria National Reserve, who participated in data collection and without whom this project would not have been possible. We thank Teddy Urashima and Pool Erazo Arevalo for field assistance, Pablo Puertas for his help and advice, Hannah Kirkland for proof reading, Fund Amazonia, Wildlife Conservation Society, Earthwatch Institute and Operation Wallacea for assistance during fieldwork and financial support, and the Peruvian Protected Area Service (Servicio Nacional de Áreas Naturales Protegidas) for providing authorization for and coordination of fieldwork. 
Author contributions Design of the data collection methods: REB and MK; logistical support in the field: REB; data collection and analysis, writing of first draft: MK; preparation of the final text: JCA, MK, $\mathrm{CE}, \mathrm{REB}$ and PM; production of the maps: $\mathrm{AB}$.

\section{Conflicts of interest None.}

Ethical standards All authors abided by the Oryx Code of Conduct. The highest standards of research ethics were followed and the necessary approvals and permits were obtained to carry out field research in the protected area and to work with Indigenous communities.

\section{References}

Abernethy, K., Coad, L., Taylor, G., Lee, M. \& Maisels, F. (2013) Extent and ecological consequences of hunting in Central African rainforests in the 21st century. Philosophical Transactions of the Royal Society B, 368, 20120303.

Atwood, T.B., Connolly, R.M., Ritchie, E.G., Lovelock, C.E., Heithaus, M.R., Hays, G.C. et al. (2015) Predators help protect carbon stocks in blue carbon ecosystem. Nature Climate Change, 5 1038-1045.

B ASSETT, T.J. (2005) Card-carrying hunters, rural poverty, and wildlife decline in northern Côte d'Ivoire. Geography Journal, 171, 24-35.

Begazo, A.J. \& Bodmer, R.E. (1998) Use and conservation of Cracidae (Aves: Galliformes) in the Peruvian Amazon. Oryx, 32, 301-309.

Bodmer, R.E. \& Lozano, E.P. (2001) Rural development and sustainable wildlife use in the tropics. Conservation Biology, 15, 1163-1170.

Bodmer, R.E., Mayor, P., Antunez, M., Chota, K., Fang, T., Puertas, P. et al. (2017) Major shifts in Amazon wildlife populations from recent climatic intensification. Conservation Biology, 52, 1-12.

Bodmer, R.E. \& Puertas, P.E. (2007) Impacts of displacement in the Pacaya-Samiria National Reserve, Peru. In Protected Areas and Human Displacement: A Conservation Perspective (eds K.H. Redford \& E. Fearn), pp. 29-33. Wildlife Conservation Society Working Papers No. 29. Wildlife Conservation Society, New York, USA.

Bodmer, R.E., Puertas, P.E. \& Fang, T.G. (2008) Co-managing wildlife in the Amazon and the salvation of the Pacaya-Samiria National Reserve in Peru. In Wildlife and Society. The Science of Human Dimensions (eds M. Manfredo, J. Vaske, P. Brown, D. Decker \& E. Duke), pp. 104-116. Island Pess, Washington, DC, USA.

Bodmer, R.E., Puertas, P.E., Garcia, J.E., Diaz, D.R. \& Reyes, C. (1998) Game animals, palms and people of the flooded forests: management considerations for the Pacaya-Samiria National Reserve, Peru. Advances in Economic Botany, 13, 217-232.

Brodizio, E.S. \& Chowdhury, R.R. (2010) Spatio-temporal methodologies in environmental anthropology: geographic information systems, remote sensing, landscape changes, and local knowledge. In Environmental Social Sciences: Methods and Research Design (eds I. Vaccaro, E.A. Smith \& S. Aswani), pp. 266-289. Cambridge University Press, Cambridge, UK.

Cardoso, A.M.C., de Souza, A.J.S., Menezes, R.C., Pereira, W.L. A. \& Tortelly, R. (2012) Gastric lesions in free-ranging black caimans (Melanosuchus niger) associated with Brevimulticacum species. Veterinary Pathology, 50, 582-584.

Castello, L., Arantes, C.C., McGrath, D.M., Stewart, D.J. \& de SousA, F.S. (2014) Understanding fishing-induced extinctions in the Amazon. Aquatic Conservation: Marine and Freshwater Ecosystems, 25, 587-589.
Constantino, P. (2016) Deforestation and hunting effects on wildlife across Amazonian indigenous lands. Ecology and Society, 21(2), 3.

Da Silva, M.N.F., Shepard, JR, G.H. \& Yu, D.W. (2005) Conservation implications of primate hunting practices among the Matsigenka of Manu National Park, Peru. Neotropical Primates, 13, 31-36.

East, T., Kümpel, N.F., Milner-Gulland, E.J. \& Rowcliffe, J.M. (2005) Determinants of urban bushmeat consumption in Río Muni, Equatorial Guinea. Biological Conservation, 126, 206-215.

Espinosa, S., Branch, L.C. \& Cueva, R. (2014) Road development and the geography of hunting by an Amazonian indigenous group: consequences for wildlife conservation. PLoS ONE, 9, e114916.

Fa, J.E., Olivero, J., Farfán, M.Á., Márquez, A.L., Duarte, J., NACKONEY, J. et al. (2015) Correlates of bushmeat in markets and depletion of wildlife. Conservation Biology, 29, 805-815.

Fa, J.E., Seymour, S., Dupain, J., Amin, R., Albrechtsen, L. \& MaCDONALD, D. (2006) Getting to grips with the magnitude of exploitation: bushmeat in the Cross-Sanaga rivers region, Nigeria and Cameroon. Biological Conservation, 129, 497-510.

Foerster, S., Wilkie, D.S., Morelli, G.A., Demmer, J., Starkey, M., Telfer, P. et al. (2012) Correlates of bushmeat hunting among remote rural households in Gabon, Central Africa. Conservation Biology, 26, 335-344.

Fragoso, J.M.V. (2004) A long-term study of white-lipped peccary (Tayassu pecari) population fluctuation in northern Amazonia. Anthropogenic vs "natural" causes. In People in Nature. Wildlife Conservation in South and Central America (eds K. Silvius, R. E. Bodmer \& J.M.V. Fragoso), pp. 286-296. Columbia University Press, New York, USA.

Gandiwa, E. (2011) Preliminary assessment of illegal hunting by communities adjacent to the northern Gonarezhou National Park, Zimbabwe. Tropical Conservation Science, 4, 445-467.

Garcia, A., Salvador, T., Vargas, G. \& Duponchelle, F. (2008) Patterns of commercial fish landings in the Loreto region (Peruvian Amazon) between 1984 and 2006. Fish Physiology and Biochemistry, 35(1), 53-67.

Godoy, R., Undurraga, A., Wilkie, D., Reyes-García, V., Huanca, T., Leonard, W.R. et al. (2010) The effect of wealth and real income on wildlife consumption among native Amazonians in Bolivia: estimates of annual trends with longitudinal household data (2002-2006). Animal Conservation, 13, 265-274.

Golden, C.D., Wrangham, R.W. \& Brashares, J.S. (2013) Assessing the accuracy of interviewed recall for rare, highly seasonal events: the case of wildlife consumption in Madagascar. Animal Conservation, 16, 597-603.

Gow, P. (2007) "Ex-Cocama": transforming identities in Peruvian Amazonia. In Time and Memory in Indigenous Amazonia (eds C. Fausto \& M.J. Heckenberger), pp. 194-215. University Press of Florida, Gainesville, USA.

Gray, C., Bozigar, M. \& Bilsborrow, R. (2015) Declining use of wild resources by indigenous peoples of the Ecuadorian Amazon. Biological Conservation, 182, 270-277.

HaWken, A. \& MunCH, G.L. (2012) Cross-national indices with gender-differentiated data: what do they measure? How valid are they? Social Indicators Research, 111, 801-838.

Hill, K., Hawkes, K., Hurtado, M. \& Kaplan, H. (1984) Seasonal variance in the diet of Ache hunter-gatherers in Eastern Paraguay. Human Ecology, 12, 101-135.

inRena (Instituto Nacional de Recursos Naturales) (2009) Plan Maestro de la Reserva Nacional Pacaya Samiria. Instituto Nacional de Recursos Naturales, Lima, Peru.

IUCN (2017) The IUCN Red List of Threatened Species 2017-3. Http://www.iucnredlist.org [accessed 4 June 2018]. 
Kvist, L.P., Gram, S., Cácares, A.C. \& Orem, I.B. (2001)

Socio-economy of flood plain households in the Peruvian Amazon. Forest Ecology and Management, 150, 175-185.

Laurance, W.F., Croes, B.M., Tchignoumba, L., Lahm, S.A., Alonso, A., LeE, M.E. et al. (2006) Impacts of roads and hunting on Central African rainforest mammals. Conservation Biology, 20, 1251-1261.

Levi, T., Lu, F., Yu, D.W. \& MANGEL, M. (2011) The behavior and diet breadth of central-place foragers: an application to human hunters and Neotropical game management. Evolutionary Ecology Research, $13,171-185$.

Levi, T., Shepard, Jr, G.H., Ohl-Schacherer, J., Peres, C.A. \& YU, D.W. (2009) Modelling the long term sustainability of indigenous hunting in Manu National Park, Peru: landscape-scale management implications for Amazonia. Journal of Applied Ecology, 46, 804-814.

LU, F. (2007) Integration into the market among indigenous peoples: a cross-cultural perspective from the Ecuadorian Amazon. Current Anthropology, 48, 593-602.

Mayor, P., El Bizri, H., Bodmer, R.E. \& Bowler, M. (2017) Assessment of mammal reproduction for hunting sustainability through community-based sampling of species in the wild. Conservation Biology, 31, 912-923.

Mayor, P., Pérez-Peña, P., Bowler, M., Puertas, P.E., Kirkland, M. \& Bodmer, R.E. (2015) Effects of selective logging on large mammal populations in a remote indigenous territory in the northern Peruvian Amazon. Ecology and Society, 20(4), 36.

McSweeney, K. \& Jokisch, B. (2007) Beyond rainforests: urbanisation and emigration among lowland indigenous societies in Latin America. Bulletin of Latin American Research, 26, 159-180.

Morcatty, T.Q. \& ValSecChi, J. (2015) Social, biological, and environmental drivers of the hunting and trade of the endangered yellow-footed tortoise in the Amazon. Ecology and Society, 20(3), 3

Naranjo, E.J. \& Bodmer, R.E. (2007) Source-sink systems and conservation of hunted ungulates in the Lacandon Forest, Mexico. Biological Conservation, 138, 412-42O.

Navaro, A.J., Redford, K.H. \& Bodmer, R.E. (200o) Effect of hunting in source-sink systems in the Neotropics. Conservation Biology, 14, 713-721.

Ohl-Schacherer, K., Shepard, Jr, G.H., Kapla, H. \& Yu, D.W. (2007) The sustainability of subsistence hunting by Matsigenka native communities in Manu National Park, Peru. Conservation Biology, 21, 1174-1185.

PARry, L. \& Peres, C.A. (2015) Evaluating the use of local ecological knowledge to monitor hunted tropical-forest wildlife over large spatial scales. Ecology and Society, 20(3), 15.

Patton, M.Q. (2002). Qualitative Research and Evaluation Methods. Sage Publications, Thousand Oaks, USA.
Peres, C.A. \& Dolman, P.M. (200o). Density compensation in neotropical primate communities: evidence from 56 hunted and nonhunted Amazonian forests of varying productivity. Oecologia, 122, 175-189.

Peres, C.A. \& LAKE, I.R. (2003) Extent of nontimber resource extraction in tropical forests: accessibility to game vertebrates by hunters in the Amazon Basin. Conservation Biology, 17, 521-535.

Peres, C.A. \& Palacios, E. (2007) Basin-wide effects of game harvest on vertebrate population densities in Amazonian forests: implications for animal-mediated seed dispersal. Biotropica, 39, 304-315.

R Development Core Team (2016) R: A Language and Environment for Statistical Computing. R Foundation for Statistical Computing, Vienna, Austria.

Richard-Hansen, C., Surugue, N., Khazraie, K., Le Noc, M. \& Grenand, P. (2013) Long-term fluctuations of white-lipped peccary populations in French Guiana. Mammalia, 78, 291-301.

Rist, J., Milner-Gulland, E.J., Cowlishaw, G. \& Rowcliffe, M. (2010) Hunter reporting of catch per unit effort as a monitoring tool in a bushmeat-harvesting system. Conservation Biology, 24, 489-499.

Roos, N., Wahab, M.A., Chamnan, C. \& Thilsted, S.H. (2007) The role of fish in food-based strategies to combat vitamin A and mineral deficiencies in developing countries. American Society for Nutrition, 137, 1106-1109.

Rubin, H.J. \& Rubin, I.S. (2005) Qualitative Interviewing: The Art of Hearing Data. Sage Publications, Thousand Oaks, USA.

Sirén, A. \& WiLkie, D. (2016) The effects of ammunition price on subsistence hunting in an Amazonian village. Oryx, 50, 47-55.

Smith, A. \& Wishnie, M. (200o) Conservation and subsistence in small-scale societies. Annual Review of Anthropology, 29, 493-524.

Suarez, E., Morales, M., Cueva, R., Bucheli, V.U., Zapata-Rios, G., Toral, E. et al. (2009) Oil industry, wild meat trade and roads: indirect effects of oil extraction activities in a protected area in north-eastern Ecuador. Animal Conservation, 12, 364-373.

VAsco, C. \& Sirén, A. (2016) Correlates of wildlife hunting in indigenous communities in the Pastaza province, Ecuadorian Amazonia. Animal Conservation, 19, 22-429.

Wilkie, D.S. \& Godoy, R.A. (2001) Income and price elasticities of bushmeat demand in lowland Amerindian societies. Conservation Biology, 15, 761-769.

Wilkie, D.S., Shaw, E., Rotberg, F., Morelli, G. \& Auzel, P. (2000) Roads, development and conservation in the Congo Basin. Conservation Biology, 14, 1614-1622.

Zapata-Ríos, G., Urgil, C. \& SuÁrez, E. (2009). Mammal hunting by the Shuar of the Ecuadorian Amazon: is it sustainable? Oryx, 43, 375-385.

Zimmerman, B., Peres, C.A., Malcolm, J.R. \& Turner, T. (2001) Conservation and development alliances with the Kayapó of south-eastern Amazonia, a tropical forest indigenous people. Environmental Conservation, 28, 10-22. 